Smoke-free bars

\section{Smoke-free bars in Ireland: a runaway success}

F Howell

\section{Banning smoking in bars in Ireland has proved extremely popular}

O 29 March 2004, Ireland became the first country in the world to implement legislation creating smoke-free enclosed workplaces that included bars and restaurants. ${ }^{1}$ While the legislation involved all workplaces, with minor exceptions, national and international media attention focused on how the legislation would be implemented in bars. Many commentators looked on in disbelief and suggested that Irish bars, globally iconic for smokin' and drinkin', would be the last place on earth one would expect to see go smoke-free. If Irish bars could successfully go smoke-free, what was the problem elsewhere?

Ireland is not alone in having smokefree bars. Since March 2004, Norway, New Zealand, Uganda, Bhutan, and Italy, have implemented smoke-free workplace legislation for all workers, including restaurant and bar workers. Before March 2004, considerable progress in implementing smoke-free restaurants and bars occurred in the USA (seven states) and Canada (five provinces) with further progress due in 2005. Elsewhere, Sweden is scheduled to go smoke-free in July 2005 and Australia by the end of 2007. In the UK, Scotland is leading the way in the fight to go smoke-free. All over the world, many countries are actively looking at the feasibility of bringing in some sort of smoke-free legislation to protect their citizens. ${ }^{2}$

While public transport, cinemas, and offices are relative policy change cakewalks, the real battle begins when governments seek to extend smoke-free legislation to the hospitality sector, especially bars. ${ }^{3}$ This was very much a feature of the situation in Ireland when smoke-free bars and restaurants were first mooted. Most of the opposition to the measure came from bar owner representatives and was similar in nature to that seen in the USA and Canada when smoke-free legislation for bars became a major lobbying focal point. As elsewhere, issues around threatened non-compliance with the new legislation and scare campaigns about the economic impact on bars dominated.
Doom and gloom rhetoric was everywhere. The reality of what happened tells a very different story.

\section{UNNECESSARY, UNWORKABLE, AND UNJUSTIFIED}

At a very early stage in the campaign, bar owner representatives constantly asked how the legislation would be "policed" in the event of non-compliance. Their approach is best exemplified by one of their representatives who stated: "We have said time and time again, this ban is unnecessary, unworkable and unjustified. Our members are not prepared to put their lives, their wives and daughters and female staff at risk. They are publicans not smoke police". ${ }^{4}$

In contrast to their concerns, compliance with the law has been extremely high. Six months after the legislation was introduced a survey carried out by the Office of Tobacco Control reporting on 26627 inspections showed compliance levels of $94 \%$. Data from the free phone compliance line which facilitated the public in notifying breaches of the legisaltion also underscores the ease with which the legislation has been implemented and enforced. In the six month period of the report, 2555 calls were made to the compliance line, peaking in the first month at 1524 and therafter showing a downward trend to 145 complaints recorded in September 2004. To date only 11 out of some 7000 bars have needed to be prosecuted for failing to implement the legisaltion. ${ }^{5}$

Public support for smoke-free bars has also increased. Despite smoking prevalance of $27 \%$, a poll commissioned by the Office for Tobacco Control before the legislation was introduced found that $67 \%$ of the public overall and nearly $40 \%$ of smokers supported the proposed law to ban smoking in bars and restaurants. ${ }^{6}$ A survey commissioned by the Department of Health and Children some months after the smoke-free initiative was in place showed that:

- $82 \%$ support the Smoke-free at Work measure
- $90 \%$ agreed that going smoke-free is of benefit to workers

- $82 \%$ agreed that it benefits everyone in public places

- $95 \%$ agreed that the legislation is a positive health measure.

The survey also reported a positive response in relation to socialising in smoke-free hospitality venues with a majority of people confirming that the smoke-free legislation improved their experience in bars $(70 \%)$ and restaurants $(78 \%){ }^{7}$

\section{ECONOMIC IMPACT ON THE BAR TRADE}

Before the introduction of the smokefree legislation, bar owners consistently stated that the smoke-free legislation would have a negative impact on their business. ${ }^{8}$ Since its introduction bar owners claim that sales are down between $15-25 \%$ with significant job losses evident, as a result of the legislation. ${ }^{9}$ The reality is somewhat different. In advance of the legislation, market research from the drinks industry showed the number of regular bar-goers had fallen by at least $20 \%$ since $2000 .^{10}$ In addition, volume sales of alcohol in Irish bars reached their peak in 2001 and had fallen by $15 \%$ even before the smoke-free legislation came into force in 2004..$^{10}$ Many reasons have been postulated for this shift: changing demographics, increasing price of drink in bars, health concerns about alcohol, commuting times, lifestyle changes such as dinner parties and nights in front of the home cinema system, and drink-driving legislation, to cite but a few.

The most recent objective data on bar sales and volumes in Ireland comes from the latest Central Statistics Office report on retail sales which shows that seasonally adjusted turnover in bars has fallen by around $3.8 \%$ in value and $5.8 \%$ in volume during the nine months the smoke-free initiative has been in place, with more recent data showing that bar sales have climbed by $2.3 \%$ in both value and volume terms between September and November 2004. Economists have stated that this trend made the claim by the Vintners' Federation of Ireland that sales were down $25 \%$ since the smoking ban was instituted "totally misleading". ${ }^{11} 12$

\section{4: HOW WAS IT FOR YOU?}

Despite all the negative rhetoric surrounding the introduction of the smokefree initiative in Ireland by vested interests, perhaps the most telling impact that it has had on the Irish population was best captured on a 
programme which was broadcast on national television on New Years Day 2005. Market research carried out for the programme "2004: How was it for you" found that from a list of 30 positive events that happened in Ireland in 2004, including many memorable international sporting achievements, the implementation of the smoke-free initiative in all workplaces topped the poll. Not only did it top the poll, it was a clear $15 \%$ ahead of the second placed event, Ireland's only Olympic Games gold medal winner in 2004.

The runaway success of smoke-free bars in Ireland has confounded and surprised many national and international commentators. In truth, the public health community in Ireland was also surprised by the ease at which the community took to it. But then again, everywhere that has properly managed the introduction of such legislation has had similar results. So, if Irish bars can successfully go smoke-free, what is the problem elsewhere? 2005: How will it be for you?

Tobacco Control 2005; 14:73-74.

doi: 10.1136/tc.2005.011304

Correspondence to: Fenton Howell, Faculty of Public Health Medicine, Royal College of Physicians of Ireland, International House 20-22 Hatch Street Lower, Dublin 2, Ireland; fentonhowell@eircom.net

\section{REFERENCES}

1 Anon. Public Health (Tobacco) Acts 2002 and 2004. Dublin: Stationery Office, 2004.

2 ASH UK. International trends towards smoke-free provision. http://www.ash.org.uk/html/ publicplaces/ html/intlawhtml (Accessed 25 January 2005).

3 Dearlove JV, Bialous SA, Glantz SA. Tobacco industry manipulation of the hospitality industry to maintain smoking in public places. Tobacco Control 2002;11:94-104.

4 Tadg O'Sullivan. VFI Members Convey Concerns at Meeting in Portlaoise. http://www.vfi.ie/ aboutvfi/article_detailasp?article_type_id $=1$ \&article_id $=41$ (Accessed 25 January 2005).

5 Office of Tobacco Control. Smoke-free workplace legislation implementation. Six months progress report. Office of Tobacco Control, Clane,
December 2004. http://www.otc.ie/Uploads/ Progress\%2Oreport\%2OFINALpdf (Accessed 25 January 2005).

6 Office of Tobacco Control. Press release. OTC/ MRBI survey shows more than two-thirds of public support proposed ban on smoking in pubs \& restaurants. http://www.otc.ie/

article.asp?article $=45$ (Accessed 25 January 2005).

7 Department of Health and Children Improvement in pubs experienced by $70 \%$ of population. http://www.smokefreeatwork.ie/ news/detailasp?id = 21. (Accessed 25 January 2005).

8 Vintners Federation of Ireland. Research Shows $10 \%$ job loss in New York pub sector since introduction of smoking ban. http://www.vfi.ie/ aboutvfi/ article detailasp?article type id $=18$ article_id = 38. (Accessed 25 January 2005). 9 Vintners Federation of Ireland. Smoking ban seriously hurting rural pub businesses - Drinks Suppliers confirm 15-25\% drop in sales. http:// www.vfi.ie/aboutvfi/ article_detailasp?article_ type_id $=1$ \&article_id $=89$. (Accessed 25 January 2005).

10 Paul O'Kane. Calling time on the pub? Sunday Tribune, 2004 February 22.

11 Una McCaffrey. Retail sales rise of $2.8 \%$ marks turnaround-CSO. The Irish Times, 2005 January 22.

12 Richard Curran. Pub sales dip raises doubt on impact of ban. The Irish Independent, 2005 January 25.

\section{The Lighter Side}
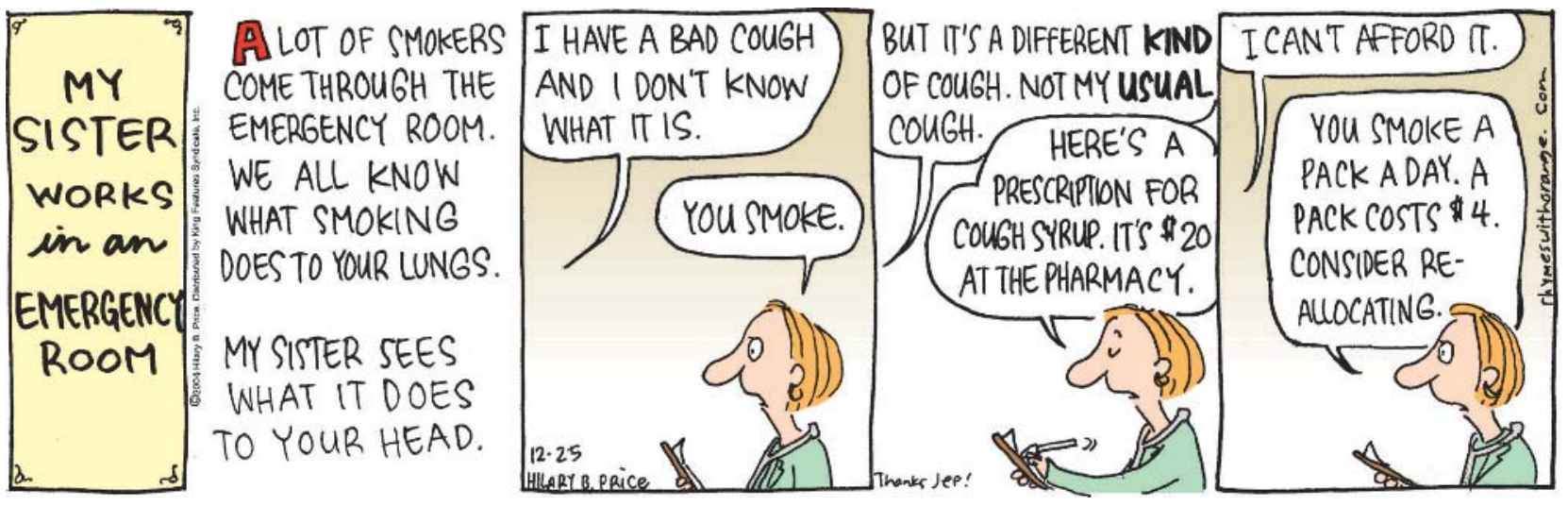

Rhymes with Orange, by Hilary Price. Reprinted with permission - Torstar Syndication Services. @ King Features Syndicate. 